\title{
The Code of Ethic and Violence against Journalists, in the Era of Press Freedom in Indonesia A Study of the GAM Conflict Period in Aceh Province
}

\section{Hamdani}

Institut Agama Islam Negeri Lhokseumawe, Indonesia

Email: hamdaniag.70@gmail.com

\begin{abstract}
:
Post-press freedom in Indonesia (the passing of Law No. 40/1999) gave rise to a variety of new problems, ranging from widespread violations of the Journalistic Code of Ethics (KEJ) to violence against journalists. In fact, the Press Law No. 40/1999 was actually born to provide fresh air for press freedom in the country and to provide the widest possible space for press operations that were previously locked in the shackles of power. The results of the discussion found that violations of the journalistic code of ethics tended to be committed by young journalists who were still raw with the articles of the code of ethics and the Press Law No. 40/1999. Forms of violation are sometimes reluctant to confirm sources, using fictitious anonymous sources, do not keep the identity of victims of immoral crimes secret, use bar language, and tend to attack individual privacy, and harass SARA - things that were previously very sacred. The results of the study prove that between press freedom and violations of journalistic code of ethics and violence against journalists have a significant relationship, while violations of journalistic codes of ethics with violence against journalists also have a significant relationship, but between press freedom and violence against journalists have a relative relationship during the conflict. Aceh does not have a causal relationship, but after the peace of GAM Aceh - RI there is a very significant relationship, in fact it was carried out by former fighting elements in Aceh GAM and the TNI / Polri. To avoid continuing victims, journalists in Indonesia, especially Aceh is expected to be able to apply the Proportional and Professional Concept (2P); Professional as a basic competency in journalistic and proportional operations is a provision to face various threats and dangers in fieldo perations.
\end{abstract}

Keywords:

press freedom; code of ethics; violence against journalists

\section{Introduction}

Various human desires, aspirations, opinions, attitudes, views and feelings can be published through the media. Likewise, the government can take advantage of the press (mass media) to convey information to the public without having to bother holding face-to-face meetings or conveying it in written form such as letters or leaflets, in a short time the information has spread widely in society.

The passing of Law no. 40 of 1999 concerning the Press in September 1999 - four months since the onset of the reform era, is perhaps the most monumental milestone in the history of the Indonesian press towards true press freedom - after decades of hanging hopes for it. If it is agreed that the beginning of the struggle for press freedom in Indonesia from the founding of the first journalist organization Inlandsche Journalisten Bond (IJB) in 1914 in Solo, then no less than 85 years of this struggle will only have its results, after going through various bitter and twisted struggles. 


\section{Britain International of Humanities and Social Sciences (BIoHS) Journal \\ ISSN: 2685-3868(Online), 2685-1989(Print) \\ Vol. 2, No. 3, October 2020, Page: 721-732}

After twenty-one years (1999 - 2020) under the current free air, the Indonesian press has experienced very significant development, this can be seen both from the number of press and broadcast publishing companies, supporting technology and from the number of media workers (journalists) themselves. Likewise with journalists' organizations. In the past, there was only the Indonesian Journalists Association (PWI) as a single organization.

Among the forms of deregulation in Law No.40 of 1999 concerning the Press is the abolition of Press Issuance Business Permits (SIUPP) for the establishment of new press publishing companies as in the previous Press Law and Permenpen. UU no. 40 also guarantees no censorship, government control and bureaucracy of the media, without the threat of arrest, trial and criminalization of journalists as in the past. Everyone is now free to set up a press publishing business, sit as editor in chief, recruit journalists and publish their media newspapers, magazines, tabloids, without being preoccupied with various conditions. Editorial leaders and journalists no longer need to be alarmed by various signs of government traps, such as arbitrary arrests and imprisonment by the police and security without trial.

Since then, hundreds of new newspapers, magazines and tabloids have begun to appear, in various provincial cities, and even regency cities throughout Indonesia. Following the passing of Law no. 32 of 2002 concerning broadcasting and Law No. 14 of 2008 concerning the disclosure of public information, also appeared dozens of television stations and hundreds of new private radio broadcasts, both headquartered in Jakarta and the regions.

This shift in values has led to a very significant change in the structure of media management, apart from demanding management specialization and journalistic competence. It is not enough for journalists to rely solely on self-taught talents and insights, but must also be supported by knowledge, skills, special competencies and also professional management.

Following the improving level of journalists' welfare, it is no longer strange that more and more people depend on their lives as media workers - not the exception of the print media, but also television and radio which are increasingly becoming the dominant coalition in the media industry arena in the country. Media owners are also busy swerving their wheels to boost performance and boost the quality, quantity of news and broadcast frequency, through the recruitment of professional young journalists with qualifications of S-1 and even Masters.

Because the tradition of "envelopes, advertisements and facilities" has been cultivated by officials, making them survive, although they must be willing to be called WTS (Journalists without Newspapers). This model group of journalists has recently backfired in journalist operations, not only in the regions but also at the central level. In their coverage they tend to ignore, even "trample" ethical values, honesty, objectivity, obligation of confirmation, fairness and balance (cover both side), on the contrary tend to be tendentious, try by the press, character assassination ), violent and sexual exploitation, and invading other privacy rights. Their reporting style was emotional, interested, partial and hiding facts as a conspiracy with certain parties. They emphasize the sensation aspect rather than the essence, prioritize the value of news (news value), favor advertisers, media owners and the rulers more than the truth, more valuable slander than information. They also do not care about the news that there is a risk of violating SARA (ethnicity, religion, race, intergroup), violating the journalistic code of ethics (KEJ) and the Press Law, using fictitious anonymous sources and other public deception. 


\section{Review of Literatures}

\subsection{Violence against Journalists}

Violence, according to Pascal Larderllier, can be defined as a principle of action based on the power to force others without consent. Violence contains elements of domination over other parties in various forms: physical, verbal, moral, psychological or through pictures. The use of force, manipulation, slander, untrue reporting, detrimental conditioning, insulting words and insults are all true expressions of violence. The logic of violence is the logic of death because it can injure the body, injure psychologically, harm and can be a threat to personal integrity.

Violence against journalists and the media is carried out by various groups of society and occurs in various forms, physical and non-physical - ranging from pressure, vandalism of offices, threats of terror (telephone / letter), severe maltreatment, murder to criminal / civil charges. Pressure from interest groups or political forces on the press in the early days of reform, such as the suspension of Indosiar TV's "Actual Dialogue" and "info for you" fixed broadcasts, the Military Military Command Lawsuit against the magazine "Tajuk", the Lawsuit by the Minister of Home Affairs Syarwan Hamid on the tabloid "Detak" The magazine "Sinar" and "Harian Merdeka", the Lawsuit by the Islamic Defenders Association (API) and 20 Islamic organizations against the magazine "Jakarta-Jakarta" are just examples of dozens of similar cases in the country.

\subsection{Journalistic Code of Ethics Violation}

Journalism in its sense, comes from the word "jour" (French) which means "diary". Since ancient Roman times, Julius Caesar, has known the word "Acta Diurma". Which means all activities from day to day (government announcements, etc.). The term journalism at this time, may already be familiar to the ear. In this current era, various information and telecommunication media greatly influence people's attitudes and behavior, especially in urban areas, even the mass media can influence people to remote rural areas. In terms of its origin, the term journalism comes from journalistiek (Dutch), similar to the term in English namely Journalism which originates from the words of the journal, which is a translation of the Latin diurna which means "daily" or "every day", where all the news on that day contained in printed sheets of paper. (Saragih, 2020).

Violation of the Code of Ethics (KE) is an act or behavior of journalists in their operation of finding, covering, writing and publishing news that is not in line (violates) ethical values that have been mutually agreed upon. The code of ethics referred to here is all ethical moral rules formulated with Indonesian journalists, both the so-called Indonesian Journalists Code of Ethics (KEWI), Journalistic Code of Ethics (KEJ) and the Independent Journalist Alliance Code of Ethics (KEAJI). In principle, the three codes of ethics do not make a significant difference in terms of content, function and definitions governing the operational performance of the press. The operation of journalists who violate or deny the ethical formulation above is considered a violation of the press code of ethics which must be sanctioned by the parent organization where the journalist is a member of and implemented by the Press Council. Serious code of conduct violations, such as writing fake news (slander) that lead to other people's victims, are reported to the Press Council for tougher sanctions. As an operational standard for the press, the code of ethics must be known and used as a signpost for every journalist in his performance, whether professional journalists (senior) or even novice journalists. 


\subsection{Press Freedom}

Philosophically freedom or the idea of being free is a complex term - it can be viewed from various aspects; from individualistic, liberalistic and socialistic aspects. The three of them interpret freedom according to their respective domains and criteria. Freedom also penetrates a very broad and diverse realm in almost all lines of life and human life, including physical and psychological aspects, material and spiritual. And even in its application, freedom can take the form of positive on the one hand and negative on the other

In philosophical studies, freedom is often associated with issues of freedom of will (free will) and action (free action). Jean-Jacques Rousseau, the French philosopher, states that freedom is related to an effort to preserve body and soul, with the implication that all social interactions of society are intended to avoid the loss of freedom, whether they like it or not. "Man is born free, but every where he is in chains". According to Rousseau, humans essentially have freedom, it's just that in their freedom they are bound by norms and values that have been formed in a system in society.

Meanwhile, Frans Magnis Suseno, classifies freedom into two; namely existential freedom and social freedom. Existential freedom is concerned with a person's ability to determine his own actions. This freedom does not emphasize the free aspect of what but is free for what. Freedom finds its positive form in deliberate action. Meanwhile, social freedom is freedom that is received from other people, so this freedom refers to the aspect of freedom from what or who. This freedom has a negative form, because a person is only called free if he is not limited by others to act. Therefore, freedom of the press is meant as existential freedom, that is, freedom of the press in carrying out its activities and duties without coercion or restrictions from other parties which cause the activity to no longer comply with its will. Social freedom also occurs in the press when certain parties are prohibited from compelling the press to perform or leave certain activities.

\subsection{Conflict as a Cause of Violence}

Conflicts, riots or wars that usually involve two warring parties and attack each other cause human casualties, both from parties to the conflict or other innocent parties. Fall victim to the other party-civil society; women, children and journalists, although protected by humanitarian law, two possibilities; deliberately like being used as a shield or accidentally hit by a stray bullet.

In the context of victims of journalists - there are also two possibilities; because of the news that provoked the anger of the parties or not because of the coverage, but because of the victims of stray bullets during war coverage or "gunfire". In the 1999 - 2011 Aceh conflict, the number of journalist victims was up to five people were killed and dozens of others experienced physical, psychological, car, house and family violence that occurred in various forms with the perpetrators of both parties fighting the Free Aceh Movement (GAM) and the Military.

It is very difficult to reveal the motive for the acts of violence against journalists during the conflict in Aceh, because the process and chronology differ from one victim to another. All that could be detected was probably the process, which was preceded by a kidnapping, shooting and torture - two days later he was found dead. From the data recorded by the Aceh Press Club in 2004, most of the motives for violence against journalists in Aceh occurred as a form of arrogance between two groups in conflict; GAM and Military, when journalists carry out their coverage in the field. Only a small part of it happened because of the reporting - and even then because of positive exposure of one party, which offended the other party, so that their anger was vented at journalists. Or news that is considered to be cornering a certain group, despite the fact that it is. The perpetrators, these two groups - if not GAM, must be the military. 


\section{Discussion}

\subsection{Press Freedom and Code of Conduct Violation}

The 2012 Press Council survey, proved that 10 percent of novice journalists have never read a code of ethics, 48 percent have read it and 42 percent stated that they have read the entire contents of the code of ethics. Therefore, according to a member of the Press Council, Nezar Patria, the most reports that have been submitted to the Press Council, are violations of the code of ethics - especially unbalanced news because there is no confirmation. Of the 233 reports of violations of the code of ethics by print and on-line media in 2012, 127 of them were unilateral news (without confirmation), the rest mixed up opinions and facts, were judgmental, inaccurate, did not hide the identity of immoral victims and had unclear sources or used fictitious anonymous sources. (Articles 5, 6, 7 and 8 of the KEJ).

The Press Council survey data above is authentic evidence, there are still many journalists who do not know the code of ethics, as basic operational guidelines for journalists. Although the location of the survey was not stated, the number of respondents in a concrete manner, the small number of survey results illustrated the naivety of the control system, the socialization of the Press Law and the awareness of press companies towards the guidance of their journalists. Mass media is a tool used in conveying the message from the source to the audience by using mechanical means of communication, such as newspapers, radio, television and etc (Saragih (2018). It is almost certain that the survey took place in Jakarta - as the capital city of a country where the number of journalists is far more than in the regions, because that is where various mass media (print, electronic and online) grow and develop. As many as 10 percent of journalists who have never read the code of ethics are mostly beginner journalists the results of new recruits, either by new media or old media and are still amateur in nature.

\section{a. Perpetrators and Chronology of Code of Conduct Violations.}

To reveal the perpetrators of violations of the journalistic code of ethics in Aceh Province in the era of press freedom, at least it can be seen from three aspects, including:

\section{Central Journalists and Regional Correspondents}

Distinguishing the two is not just to reveal discrimination in status and welfare but more than that - related to freedom and professionalism in carrying out a profession. Journalists who work in Jakarta, on average, can live their profession freely and professionally, without significant obstacles from both the internal media owner and the external public. Central journalists can be defined as journalists who work in Jakarta, either at the head office of the media or as correspondents for media published outside Jakarta. Meanwhile, regional correspondents are journalists who work in the regions, whether the media is in the regions or correspondents from the Jakarta media.

In terms of freedom of expression, for example, in Jakarta there are hardly any persons or parties (individuals, institutions or groups) who are anti-press freedom, which have started rolling in the country since the enactment of Law no. 40 of 1999. Even if there were discordant voices shouting the press "going too far" and acting "euphoric" in the news only at the beginning of the reformation, so that the public responded with tantrums, demonstrations and violence against the press community, it was only temporary like culture shock. for changes in press performance. The proof, now the people of Java Island, especially Jakarta, are calm and positively welcome press freedom as the realization of information services and part of human rights. 
Unlike journalists in the regions, the arrogance of the authorities and regional officials is enough to make journalists shackle their freedom in carrying out their journalist profession. That is not to mention the crime mafia - such as the lottery mafia in Medan, the drug mafia in Aceh, the timber mafia in Riau, and project mafia in various regions that always haunt journalists' freedom in carrying out their duties. For them, press freedom is the death knell, because journalists are more dangerous than the police or other law enforcement agencies. If the case is published by journalists in the mass media, it is very likely that their business history will end, because in addition to being reported continuously by many media, the investigation is also not only by one legal institution but inviting all parties. That is why the crime mafia until the end of the world will never accept press freedom, let alone partner with journalists.

If you want to be honest, actually no journalist wants and has the heart to violate the journalistic code of ethics in all forms of reporting activities, because it is very contrary to the values of press idealism, principles of justice, objectivity and truth. Idealism alone is enough for a journalist to build a spirit of upholding the truth and fighting all forms of injustice, discrimination, crime in society.

\section{Professional Journalists and Beginners}

There are significant differences between pro (professional) journalists and novice journalists (amatiran), especially related to competence, journalism insight, reporting strategy, professionalism and ethics. The position of pro journalists is usually more established and profitable, no matter which media they work for, even in the yellow media which is just standing by, pro journalists are often the core staff who are properly paid. Experience, insight and ethics make his personality more respectable than novice journalists. For this reason, pro journalists are usually more committed and consistent to the code of ethics than novice journalists, even though there are also one or two pro journalists who behave like amateur journalists even worse.

Several factors cause pro journalists to adhere to the code of ethics, including:

1. Experience, journalistic insight and older age are often role models for novice journalists, so that there is a feeling of shame in violating the code of ethics - which are signs of ethics in journalism practice.

2. On average, pro journalists have read the entire contents of the KEJ or KEWI, so there is no reason to say they do not know or have accidentally violated the code of ethics.

3. Be aware and have a greater moral responsibility to always uphold the code of ethics, which is nothing but the journalists' own agreement to safeguard the dignity of journalists.

Meanwhile, even professional journalists are prone to violating the code of ethics because experience, awareness and having read the code of ethics repeatedly are not guarantees not to violate the code of ethics. The upholding of a code of ethics by the journalist community in a media depends on two parties;

First; the behavior of journalists, which must depart from the attitudes and character, as well as high idealism to fight the savage attitude and greed that afflicts every human being.

Second; the attitude of the media owner (owners of capital), do not only dare to establish the media and recruit journalists, but very few who dare to provide adequate welfare to employees and journalists. Let alone giving share ownership and profit sharing at the end of the year, monthly welfare is poor because the company is not yet capable, for reasons that the new media has risen and so on. If these two aspects run according to their portion, on the one hand the journalist has the behavior, character and idealism of the press from the conscience and on the other hand the media owner is not merely provit oriented (profit hunting) but also thinks 
about the welfare of his journalists, it is believed that violations of the code of ethics can be pressed as minimal as possible.

\section{Print or Electronic Media Journalist}

Even though they have the same status as press and information hunter, there are significant differences between print and electronic media journalists. At least, in data collection - if print media journalists only target written data and few sources of information, while electronic journalists - especially television, they also need visuals. Therefore, for TV journalists they cannot cover news randomly if it is not supported by visuals. For example, news about cases of suspected corruption, irregularities or affairs involving many public officials. Unlike the print media journalists, few negative issues concerning public figures can be directly reported or simply pretend to confirm.

So, between the negative issues and the confirmation - frequent violations of the code of ethics, especially in relation to negotiating "bartering" news with "envelopes" or "advertisements". Things like this have become common knowledge among journalists, not except in the regions but also in Jakarta.

\subsection{Form of Code of Conduct Violation}

On the other hand, the essence of code of conduct violations is ignoring crosschecks (confirmations) with news sources, because this is where other Code violations are born, such as being impartial, judgmental, inaccurate, unfair, mixing up facts and opinions, tendentiousness. , is worth slander and lies and others. That is why Islam requires that people who get news (from fasiq people) should "examine (fatabayyanu)" the truth of the information, so that they do not take wrong actions and make decisions (QS. Alhujarat: 6).

Research in the meaning of paragraph 6 of the Alhujurat above, it is intended as a confirmation or crosscheck to the parties related to the news, because it could be that the news anchor is fasiq, incompetent, interested or unsound, so that journalists get more accurate information.

That is why, the reporters' confirmation stage to news-related parties is an important stage that should not be ignored, just for the classical reasons of rushing deadlines, difficult to find, unanswered calls / text messages, etc. Moreover, including intentionally reluctant to confirm for other reasons that are not logical. If you do not want to be called a provocative journalist, bearer of slander or being labeled as a liar by the public.

The process of violating the Code of Ethics by the journalists mentioned above, some of it may be known or even at the request of the editor or media owner, because it can boost consignment circulation of newspaper sales. However, there are also many cases of Code of Conduct violations that the editors and media owners do not know at all and are not even aware of - but purely on the will of the journalists themselves. This latter case is usually carried out by regional journalists (correspondents) who are on duty far from the editorial office.

Based on the description above, it can be concluded that violations of the code of ethics by journalists have occurred sporadically - especially by novice journalists, because they do not know much about the articles of the code of ethics so they are less sensitive to ethical values and professionalism of journalism, but there are also which is done individually on purpose for personal or media gain. The intensity is felt to have increased significantly after press freedom was marked by the enactment of the Press Law no. 40 of 1999. 
Moments of press freedom, which include uncensored, unbreded, without SIUPP and without broadcasting restrictions, are interpreted euphoriaally by the press community so that they are vented as free to write about anything, anyone, anywhere and anytime, and in any form without reservation.

\subsection{Relation of Press Freedom and Violence against Journalists a. Relation of Press Freedom and Violence against Journalists}

To discuss the connection between violations of the journalistic code of ethics with acts of violence against journalists, we must go back to back - especially those discussing the process of violations, perpetrators of violations and forms of violations of the journalistic code of ethics by journalists. And the section that discusses the perpetrators, chronology, forms and victims of violence against journalists.

First, that violations of journalistic code of ethics are generally committed by novice journalists, because they do not know the details of journalistic code of ethics, so they are less sensitive to the ethical values and professionalism of journalists. The classic reason is that the media owners do not care about financing education and training for journalists. Apart from that, there are also investors who instruct their journalists to postpone confirmation so that the news value is fresher and hotter. What is clear is that the intensity of violations of the code of ethics is felt to have increased significantly after press freedom was marked by the enactment of the Press Law No. 40 of 1999. The moment of press freedom which includes uncensored, unbredel, without SIUPP and without broadcasting restrictions - for the media and protected by law and with the right to refuse - for journalists, is interpreted euphoriaally by the press community. Thus, they tend to be vented as free to write about anything, to anyone, anywhere at any time, and in any form without reservation.

Second, the more dominant perpetrators of violence against journalists are the authorities through the hands of their bodyguards, crime mafia or political movement groups, which are classified as proveledge groups. Even if, initially it is done individually, then the institution is involved to justify and get moral support. The involvement of institutions in several cases of violence against journalists seems to be defending their members - at least as pressure in law enforcement.

Before getting to the indication of the linkage of violations of the journalistic code of ethics with violence against journalists, it is necessary to first identify the motives and causes of the violence itself. Whether, the motive is journalistic activities - such as news content, news coverage, photographing sources or confirmation moments or other motives - non-journalistic activities such as victims of political conflicts, crimes, personal grudges, and others.

Thus, victims of violence against journalists in Aceh can be divided into two categories, namely; victims during the Aceh conflict before the signing of the Memorandum of Understanding (MoU), Helsinki, 15 August 2005 and victims of violence after the MoU until 2011. This categorization of victims aims to distinguish journalists' operational conditions in the conflict era and post peace. Which psychologically affects the perpetrators of violence and journalists themselves.

\section{b. Relation of Press Freedom and Violence against Journalists}

The enactment of press freedom in Indonesia, following the passing of the Press Law No.40 of 1999 was greeted with euphoria by some of the press - both in the regions and in the center (Jakarta). Euphoria alone, perhaps it is understandable - understanding freedom from being confined for decades under the shackles of a "doubtful" ruler. However, the problem 
arises when euphoric attitudes are vented in press operations - both when covering, writing news and constructing facts as well as when facing public complaints.

If this euphoria of the press is allowed to take a long time, it can give rise to an antipathy attitude and a lack of public sympathy for the press. Because, euphoria not only makes media news messy, but also unconsciously creates selfish, arrogant and proud attitudes towards others. From here, the beginning of all negative public attitudes towards the press, after reformation including physical violence, threats and intimidation. The facts so far show that since post press freedom (1999), cases of violence against journalists have increased significantly - both in quality and quantity. Both physical violence where the victim died, serious / minor injuries, and nonphysical such as threats, intimidation, terror, the victims were psychologically disturbed.

Press freedom has broken the taboo - the taboo media coverage of certain individuals, institutions and groups, in the past. During the New Order era, apart from the Press Law and Code of Ethics, the government still added a standard rule called "10 Do not" to guide the press to remain polite. Unfortunately, this standard rule is then seen as equivalent to the Press Law and the code of ethics, where action is taken for violators, even though its initial function was merely a sign to guide novice journalists. In fact, it must be admitted that the euphemism (language refinement) of the press in the past gave birth to a press that was polite, beautiful and always created an atmosphere of harmony in the midst of a religious society.

However, what the post-reform press has shown - wild, fierce, brutal, fulgar as if there are no moral and ethical boundaries to hinder it. So, although, it is not exactly the same as the Liberal press system prevailing in Western countries, the current performance of the Indonesian press is no longer worthy of being called a social responsibility press system (Social Responsibility).

On the basis of the reasons above, it can be assumed that between press freedom and violent behavior against journalists there is a significant causal relationship. This means that the freedom of the press that was promulgated by the Press Law No.40 of 1999 can cause extreme changes in the performance of the press which is vulgar and open, so as to provoke violence against journalists. So, it can be assumed that: "Press freedom can be one of the reasons for the increase in violent behavior against journalists".

\section{c. Relation of Press Freedom and Journalistic Code of Ethics Violation}

The facts show that since press freedom rolled around, the press has suddenly turned into a giant creature ready to prey on anyone, only (for the sake of) human rights called public information, even though it has to trample the human rights of some other humans. This is the face and performance of our press that is free but maybe no longer responsible (social responsibility), but is already similar to the Liberal press adopted by Western countries.

Thus, legally it is felt that the freedom of the press is very complete in carrying out its profession - there is not a single article in the Press Law that provides an opportunity for the public to bring journalists to the legal table - criminal or civil, with regard to the news. In fact, with the use of the Press Law no. 40/1999 (lex specialis) instead of the Criminal Code (lex generalis) by the police in cases involving journalists, the less likely it is that journalists can be brought to court. This fact is what makes journalists even more courageous and arrogant in writing news as they please, without paying attention to ethical values - as the only moral instrument that ensures that the press remains consistent in carrying out its profession well, amidst the current "press freedom". 
Based on the explanation above, it can be assumed that Press Freedom has a significant causal link with violations of the journalistic code of ethics. That is, the concept of press freedom according to the Press Law no. 40 of 1999 can lead to the birth and increase in cases of violations of the journalistic code of ethics by journalists - especially if this press freedom is allowed to continue as seen today, namely press freedom without protection such as sanctions against rogue media owners.

The relationship between the three concepts used in this research can be described in the following schema:

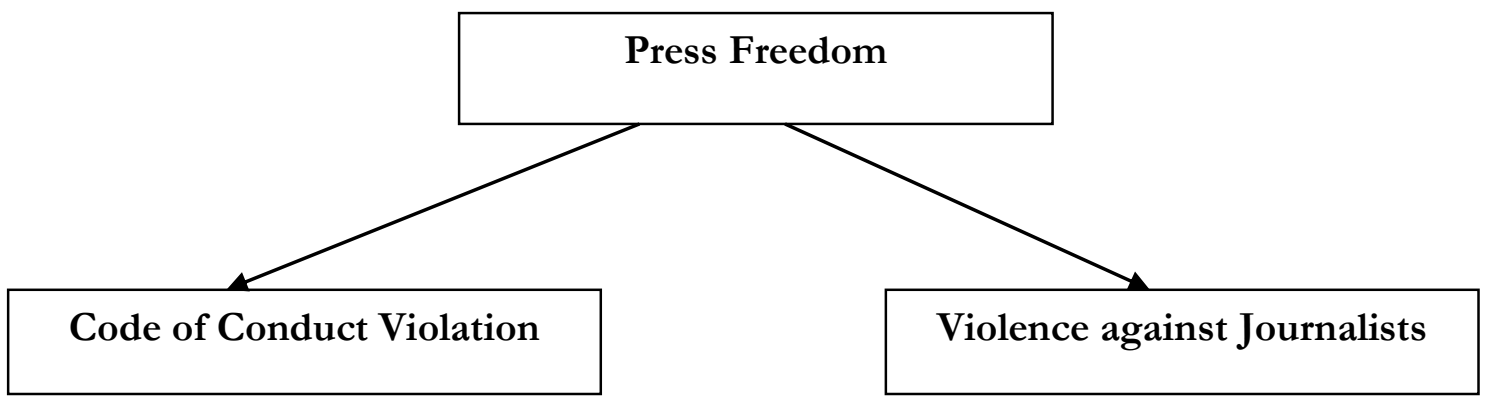

Figure 1. Press Freedom and Code Violation with Actions of Violence against Journalists.

From the chart above, it can be explained that the concept of Press Freedom as an independent variable has a direct cause and effect relationship to the two concepts of Journalistic Code Violation and Violence against journalists which are dependent concepts. This means that the concept of freedom of the press is the cause and effect (causality) of the birth of two other concepts; Code of Conduct Violation and Violence against Journalists. This argument is based on the fact that since the rolling of press freedom (in 1999) cases of code of ethics violations and violence against journalists have increased significantly.

\section{Conclusion}

At the heart of the problem, press freedom is the trigger for code violations and violence against journalists. The problem is that freedom of the press (Law on Press No. 40/1999) which is not accompanied by protection from various possibilities damages it. One of them, there are no strict rules (legally) on the obligations of press company owners to foster, provide welfare and adequate legal protection to journalists. This protection becomes important when many journalists violate the code of ethics themselves and become victims of violence whose cases continue to increase. Therefore, one solution is to protect press freedom through amendments to the Press Law No.40 of 1999 or by a stronger and more stringent Press Council regulation, so that media owners feel "self-aware" of their obligations.

On the other hand, the Press Council, Editor-in-Chief and press workers themselves are always active and consistent in exercising self-control to keep the operational system in line with the Social Responsibility Press System which is felt to be in accordance with the personality and ideology of the Indonesian nation. Ironically, since the reformation, it seems that the operation of the national press has emigrated to the Liberal Press system - adopted by the United States and other Western countries.

When the prevalence of violence against journalists has increased sharply since press freedom began, it is felt that journalists are no longer sufficient only to have journalistic competence and professionalism but must also be armed with a proportional attitude. Professionals are only equipped to be able to carry out the journalistic profession properly, 
reliably and with quality. Meanwhile, proportional is the ability to detect danger, read situations, smell signs and place oneself in certain emergency situations - such as in situations of the Aceh conflict and when journalists are dealing with criminal gangs (mafia). Thus, professionals to guide operations internally and proportionally to warn operations at the external level. So, the professional and proportional concept (Concept 2-P) is believed to be a new concept as the operational standard of the press in an effort to reduce the number of violence against journalists, as the recommendation of this research.

Evidently, during the Aceh conflict the most victims of violence were novice journalists - who misplaced the idealism of their press, while senior journalists, who on average had a proportional attitude, were barely touched by violence. The ability to detect hazards, read emergency situations, smells unfavorable signs and be able to put oneself in certain situations and conditions - turned out to be determinants of safety for journalists.

\section{References}

Adil, Indra. (2007). The Lady Di Conspiracy. Jakarta: Pustaka Al-Kautsar.

Bungin, Burhan. (2006). Sosiologi Komunikasi. Jakarta: Kencana Prenada Media Group.

Camara, Dom Helder.(1971). Spiral Violence. London: Sheed and Ward.

Denzim, Norman K \& Lincoln, Yvonna S.(2010 ). Qualitative Reasearch (Ed). California: Sage Publication.

Emka, Zainal Arifin. (2005). Wartawan Bisa Salah. Surabaya: STIKOSA-AWS.

Fajar, Marhaeni. (2009) ). Ilmu Komunikasi; Teori dan Praktek. Jogyakarta: Graha Ilmu.

Harahap, Krisna. (2000). Kebebasan Pers di Indonesia. Bandung: Grafitri Budi Utami.

Ishwara, Luwi.( 2005). Jurnalisme Dasar. Jakarta: PT.Kompas Media Nusantara

Kasman, Suf. (2004). Jurnalisme Universal. Bandung: Mizan Media Utama.

Khoirul Anam, Faris. (2009). Fikih Jurnalistik. Jakarta: Pustaka Al Kautsar.

Larderllil, Pascal. (2003). Violence Mediatiques. Paris: L'Harmattan.

Manan, Bagir.( 2010). Menjaga Kemerdekaan Pers di Pusaran Hukum. Jakarta: Dewan Pers.

Moleong, LJ.( 2006). Metodelogi Penelitian Kualitatif. Bandung: Remaja Rosdakarya.

Masduki. (2006). Jurnalistik Radio. Jogyakarta: LKIS.

McQuail, Denis. Mass Communication Theory, Second Edition. Terj. Jakarta: Erlangga, tt

Merrill, John C. (1994). Global Journalism; Survey of Intternational Communication. New York: Longman Publisher.

Nuruddin. (2007). Pengantar Komunikasi Massa. Jakarta: Radja Grafindo Persada.

Rakhmat, Jalaluddin. (2007). Psikologi Komunikasi. Bandung: Remaja Rosdakarya.

Rivers, William L- Jay W.Jensen - Theodore Peterson. (2003). Mass Media and Modern Society. terj. Jakarta: Prenada Media.

Roger, Everett M \& Shoemaker, F.Floyd. (1971). Communication of Innovation; A Cross Cultural Approach. New York: Free Press.

Sagala, Syaiful. (2009). Kemampuan Profesionalisme Guru dan Tenaga Kependidikan. Bandung: Alfabeta.

Said, Muhammad H. (2007). Aceh Sepanjang Abad, Medan: Harian Waspada.

Salmi, Jamil.( 2005). Violence and Democratic Society. New Approaches to Human Rights. Jogyakarta: Pilar Humania,

Santoso, Thomas. (2002). Teori-teori Kekerasan. Jakarta: Ghalia Indonesia

Saragih, M.Y., et al. (2020). The Challenges of Print Media Journalism in the Digital Era. Budapest International Research and Critics Institute-Journal (BIRCI-Journal). P. 540548. 
Saragih, M.Y., et al. (2018). Some Characteristics of Islamic Journalism Based on Al Quran. Budapest International Research and Critics Institute-Journal (BIRCI-Journal). P. 0110.

Surjomihardjo, Abdurrachman.(2002). Sejarah Pers di Indonesia. Jakarta: PT.Kompas Media Nusantara.

Shaffat, Idri. (2008). Kebebasan, Tanggung Jawab dan Penyimpangan Pers. Jakarta: Prestasi Pustaka.

Tornquist, Olle - Stanley Adi Prasetyo - Teresa Birks. (2010). Aceh; Peran Demokrasi bagi Perdamaian dan Rekonstruksi. Jogyakarta: PCD Press.

Tasrif, Suardi. (1994 ). Pers Bebas dan Bertanggung Jawab. Jakarta: Harian Kompas.

West, Richard \& Turner, Lynn H.(2007). Introduction Communication Theory; Analysis and Application. New York: Mc Graw Hill.

Wok, Saodah, et.al. (2004). Teori-teori Komunikasi. Pahang Darul Makmur: PTS Publication \& Distribution SDN, BHD. 